\title{
DEVELOPING MARKETING OF CASSAVA CHIPS BY PRODUCT DIVERSIFICATION AND PACKAGING IN MANGKALAYA, SUKABUMI
}

\author{
Siti Chairiyah Batubara ${ }^{1 *}$, Levyda Levyda ${ }^{2}$ \\ ${ }^{1}$ Faculty of Food Technology, Sahid University, ${ }^{2}$ Faculty of economic and business, Sahid University \\ *siti.chairiyah.batubara@gmail.com
}

\begin{abstract}
This program was aim to developing marketing on two small entrepreneurs that produce cassava chips in Mangkalaya, Sukabumi. They have been run their business in many years but they have not yet able to reach market by their own brand. Partners have not been able to improve their position in the cassava chips business. Theyonly serve as a provider for some cassava chips businesses that already have brands on the market. In term of production, it still did not meet the standards of good Manufacturing Practices (GMP). This activity was aim to improve their competitiveness on marketing by developing product. This activity provided some training such as GMP, diversification product by taste and packaging and also by market segments. The implementation of program giving some improvement namely (1) Partners have knowledge about the provision of hygienic cassava chips; (2) They able to modifying their product by having many various both in taste, packaging and market segments. (3) They have more attractive packaging of cassava chips.
\end{abstract}

Keywords: cassava chips, marketing, packaging, Sukabumi

\section{INTRODUCTION}

Production of cassava in the period 2011-2015 ranges from 21-24 million tons per year (BPS, 2016). The purpose of processing cassava is to increase the durability of cassava so that it is suitable for consumption and using cassava to obtain a high selling value in the market (Rangkuti et al, 2015). As a food ingredient, cassava has a very adequate nutritional value even if consumed as a single food lower in protein compared to rice. But even as a substitute food or additional staple food with relatively cheap prices cassava is very helpful for low income people. Cassava plants are tropical tubers and are a calorie source of increasingly cheap food in the world (Agustiar, 2012). Cassava can be processed into snacks in the form of cassava chips.

Cassava chips business opportunities themselves have bright prospects if the management is run properly, because it is usually easily available in shops, shops and supermarkets. The price is also affordable and better quality with a crunchy and savory taste. In addition, cassava chips can be used as souvenirs (Hayatun, 2013). Cassava chips business requires a market development strategy to develop its business. Promotion strategies can be carried out by introducing and communicating products through collaboration to minimarkets (Hayatun, 2013). Cassava chips consumers are very concerned about packaging, brand and price factors (Syaputri, 2015).

\section{METHOD}

Science and Technology Activities for the Community were carried out on two cassava chip craftsmen partners namely Mr. Usep Supandi and Mr.Parta who were two small cassava chips entrepreneurs located in Mangkalaya village, Sukabumi. The selection of the two SMEs is based on similar and consistent production fields. This activity was carried out by visiting both partners to get the real conditions in the field and in order to collect data. The data collected is divided into primary data, namely data from the first source (SME owner) and secondary data, namely data that has been provided by partners. Interviews and observations were conducted to get an overview of the business processes carried out by the two partners. 


\section{Situational Analysis}

Mr. Usep Supandi and Mr. Parta. Pak Parta has been in the business since 1993. As for UsepSupandi, he just started his business in 2008. Halal certification and P-IRT permits have been applied in every production process. Production activities carried out in a simple building and the building facilities are gradually being refurbished to improve the quality of the products produced. The amount of production from the cassava chips business is strongly influenced by the amount and quality of available raw materials and the amount of market demand. In the production process Mitra I already uses more hygienic equipment. As for the equipment used by partners, some have been made from stainless steel. However, the production space still does not meet the requirements of a Good Processed Food Production, especially in the production line and layout. An overview of the production space and partner equipment can be seen in Figure 1.
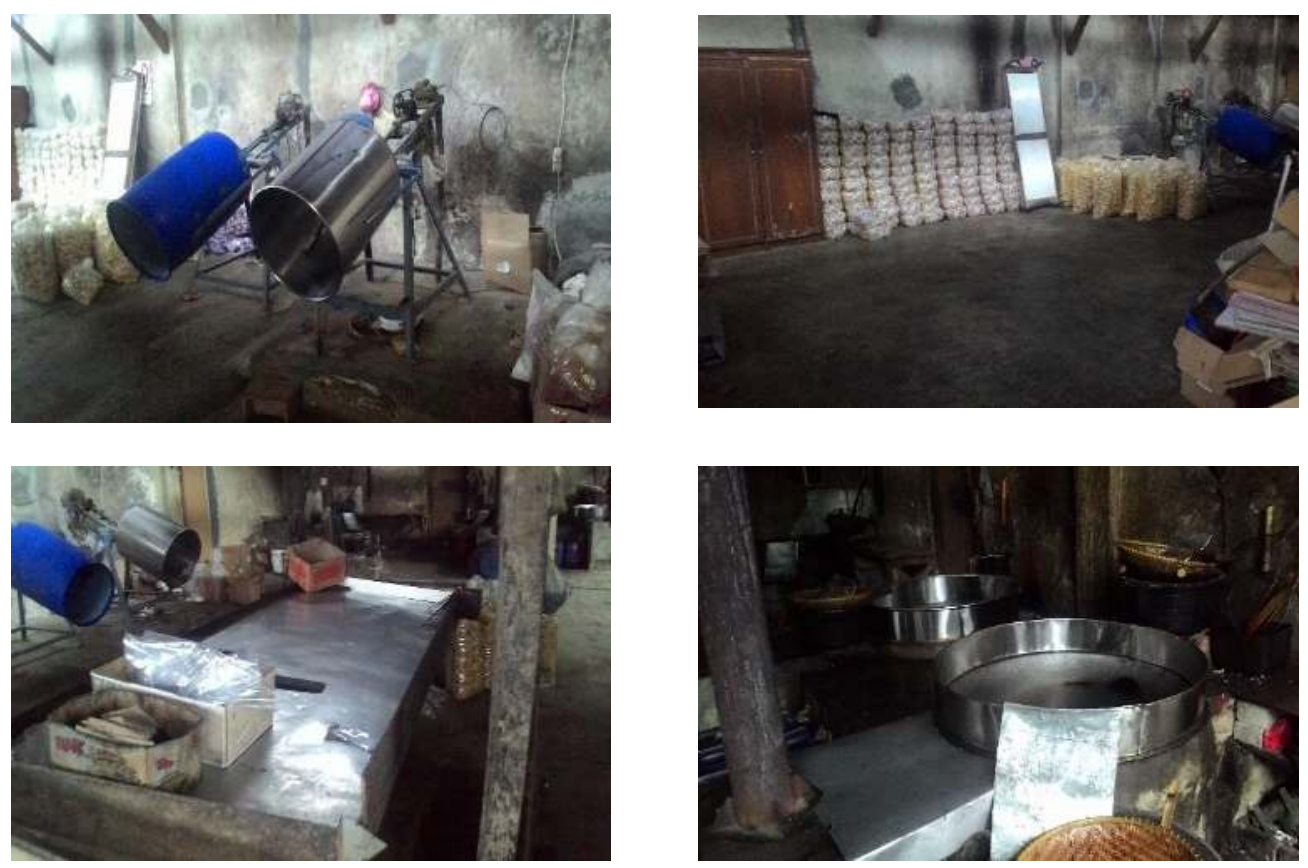

Figure 1. An overview of the production space and partner equipment

Production facilitation sanitation also still inadequate, many roofs are dusty, dirty and building designs are difficult to clean. Some parts of the floor of the production area are damaged because at night the car must park inside so that it needs a better layout. This condition is possible due to the lack of partner knowledge regarding the application of processed food production methods that are good for the market position. This is in line with what Lisyanti (2008) said that small and medium industries are usually difficult to develop due to lack of knowledge about management, marketing, processing and especially awareness of the importance of product quality which is rather 'neglected' because it requires more effort in terms of its application. If the small industry has paid attention to the quality of raw materials, the production process and finished products, then naturally the supply position in the market will be stronger with a higher selling price. One way to improve quality is to apply CPPOB, which is a guideline for how to produce food by paying attention to various aspects of sanitation. Food sanitation is the first thing mentioned in the Food Law No. 7/1996 in the section on food security, namely that the government sets sanitation requirements in the activities or processes of production, storage, transportation and or food distribution. The application of CPPOB or a good method of production is one indicator that sanitation in production operations has been carried out well.

The results of the situational analysis also show that the partner's production process is still fixated on the traditional concept, namely producing chips according to market demand and focusing 
more on quantity, while quality or quality factors are still not the main focus. According to Muhandri et al. (2016), the main limitation of MSMEs is the inability to provide quality assurance to consumers for the products they produce. Food companies, in this case chips SMEs need to implement a quality assurance system in order to strengthen competition in the global era (Karipidis et al. 2009). Quality assurance is an activity that is applied in the quality management system to ensure that a product will meet quality requirements (Husaini, 2008). According to Wahyuni et al. (2017), Quality or quality factors are important because consumer preference onchips, lies in the quality component. For consumers, quality is first priority. The minimum basic requirements for providing food quality assurance for customers are applyingGood Manufacturing Practices Method (GMP) (BPOM, 2013).

The food industry can produce quality food products through GMP, suitable for consumption, and safe for health (Alegantina et al. 2008). These basic requirements often cannot be fulfilled by food SMEs. The results of research by Yuwono et al. (2012), found only 42 fish fillet industries that applied CPPBIRT. The lack of implementation of GMP in food SMEs has resulted in low competitiveness of SMEs. Chips consumers prefer chips that meet food quality assurance. What can be done in order to improve the competitiveness of SMEs chips is to provide awareness about the importance of food quality assurance through the application of GMP. The application of GMP in chips, will produce quality food, safe for consumption, and in accordance with the demands of consumers both domestic and international consumers. Specific objectives that can be done are to provide basic principles in producing good food and direct SME chips to meet various good production requirements such as location requirements, buildings and facilities, production equipment, pest control, employee hygiene, process control, and supervision.

Marketing activities of cassava chips products are carried out independently. MrPartasoldall cassava chips to hawker sellers at the cisaat market and cibadak market, Sukabumi District with a retail price of Rp. 1000 in a small plastic bag. As for MrUsep, products are marketed in the Sukabumi, Jakarta, Bogor, Depok, Bekasi, and Tangerang regions. Distribution and sales are still carried out by the themselves. Business management is still simple. The profit and loss calculation is calculated every day by calculating the amount of raw material for cassava that comes. The production process continues every day and does not take into account in detail the amount of profit or loss of production. Sometimes, sales only cover production costs and even lose money. Employees are paid daily. Within a day, partners are able to process cassava up to 2 tons. Of all the cassava parts, $15 \%$ of the skin is wasted as untapped waste. The yield obtained is around $25-30 \%$. The production of cassava chips is usually sold as a bulk product to other cassava chips entrepreneurs who lack traditional stock and markets in small packages.

The high and low level of product sales can be caused by the appearance of a product that is less attractive, or the product has experienced a period of decline in the product life cycle. The appearance of a product is affected by product attributes. According to Stanton (1991), product attributes include price, brand, packaging, product guarantee, color, seller's good name, seller's service, quality. The attractiveness of packaging is very important in order to capture the stimulus by consumers that is conveyed to producers so that consumers are attracted to the product. Packaging will provide practical appeal for consumers, namely the effectiveness and efficiency of a package that is aimed at consumers (Wirya, 1999). Swastha (1999) states that packaging changes are intended to 1) overcome the problem of decreasing sales and 2) expanding the market by entering new consumers. As for the product life cycle, the product will experience a decrease in sales when the product has gone through the maturity stage. Therefore, it is necessary to develop products as one of the marketing strategies (Boone\& Kurtz, 2002).

Based on the identification of the problem, adequate knowledge from the proposer can provide a solution to the problems experienced by the partner. The low level of partner product sales can be overcome by 1) increasing product competitiveness in the market through the application of good processed food production methods; 2) product development on the product packaging side; 3) implementing business management in the management of cassava chips business. The partner problems related to lack of knowledge about CPPOB are well overcome by CPPOB training and structuring the production layout.

Based on deliberations with the partner, it was agreed to prioritize the following activities:

1. Carry out training / mentoring activities in the implementation of CPPOB

2. Conduct Cassava Chips Business Process Management training / assistance 
3. Conduct training / mentoring technology development product packages through packaging design and labeling.

4. Carry out assistance in product marketing using product packaging designs developed.

\section{RESULT AND DISCUSSION}

The programmeimplementation produces a variety of new products and new market segments. New products developed based on packaging design and market segment division. Diversification of packaging is divided into plastic packaging and aluminum foil packaging with a net fill weight of $150 \mathrm{~g}$. The division of market segments is based on product diversification. Products are divided into three segments, namely traditional market segments, producer segments and middle to upper consumer segments. In the traditional market segment, cassava chips are packed with small plastic packages sold at Rp. 30,000, - / bal. This segment product is the lowest grade chips with spicy taste. Products for the producer segment are medium grade products with original taste. Products in this segment are sold in kilos. The products in this segment are intended for chip producers who are chips craftsmen who have become customers. The middle to upper consumer segment is medium to very good cassava chips which are packed with plastic and aluminum packaging with a label. This product is made with various flavors, namely: original, cheese, green chili, barbeque and spicy cheese. The results of the implementation of the development of cassava chips products can be seen in Figures 2, 3 and 4.

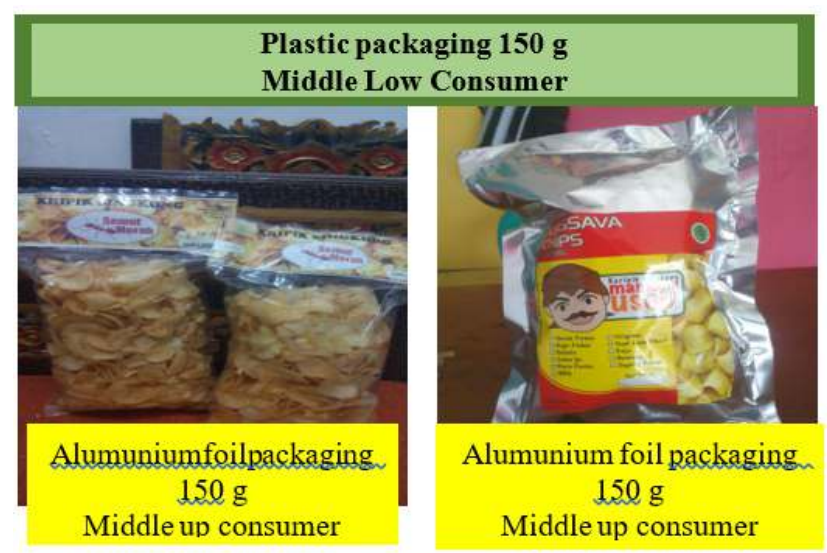

Figure2. Product diversification by packaging and market segment

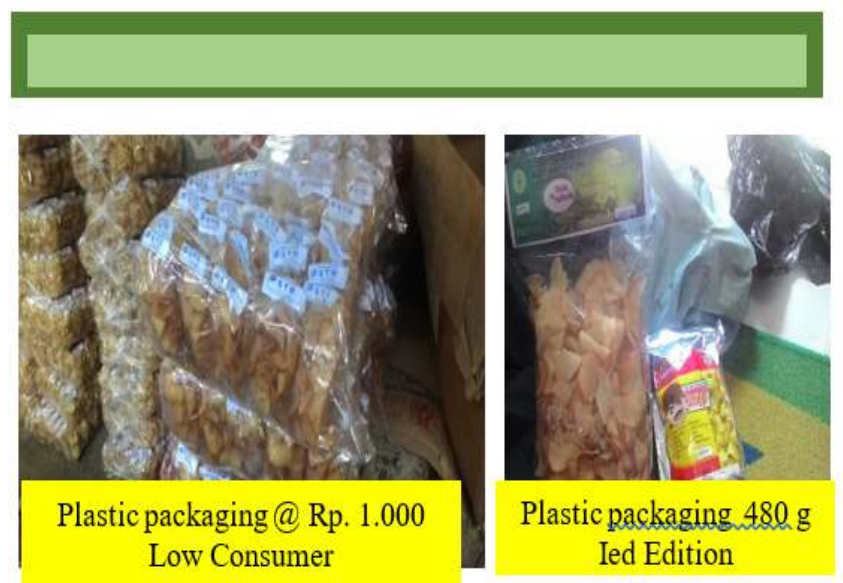

Figure3. Product diversification by market segment

Regarding the implementation of $\mathrm{CPPOB}$, it is carried out through the following activities: 
1. Renovation of the factory location as well as a re-arrangement of the layout of the factory facilities adjusted to the fulfillment of CPPB-IRT requirements. According to Wignjosoebroto (2003) facility layout is the procedure for setting up factory facilities to support the smooth production process. According to Susetyo et al. (2012), the material handling system that is less systematic in the facility layout becomes a problem that is quite large and has an impact on the production process so that it is necessary to handle the management of facilities that can support the smooth flow of materials.

2. Making process flow in the production of chips, to identify control points for potential cross contamination.

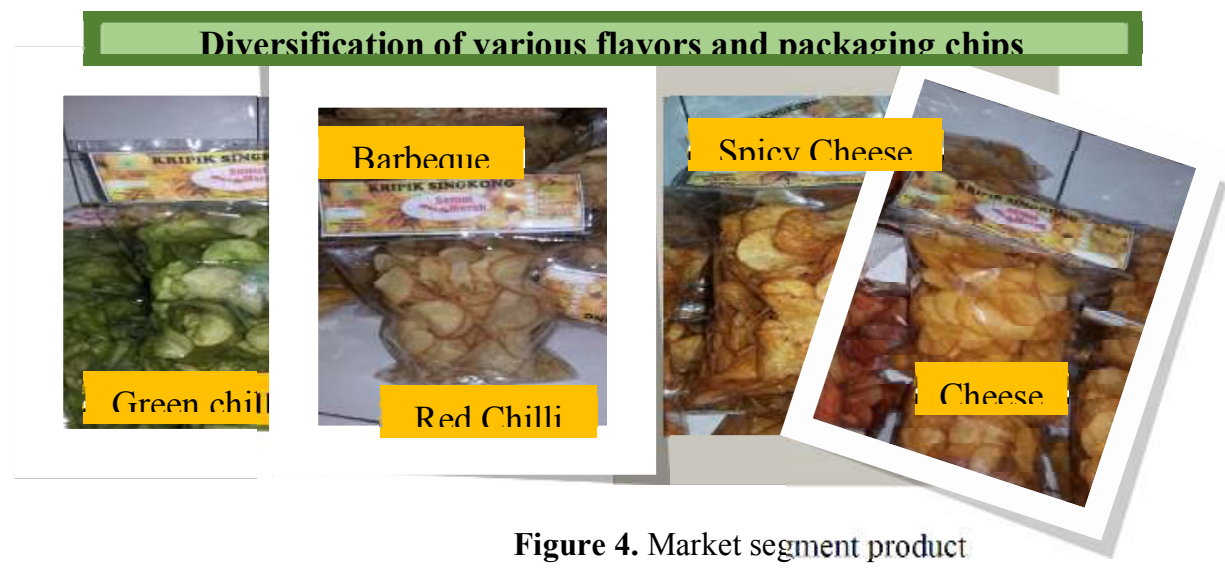

The implementation of this activity also succeeded in building a simple marketing place that was established by utilizing the part of the house that was not used. The existence of this marketing place will help partners more easily introduce products and closer to their customers. Marketing Stores can be seen in Figure 5.

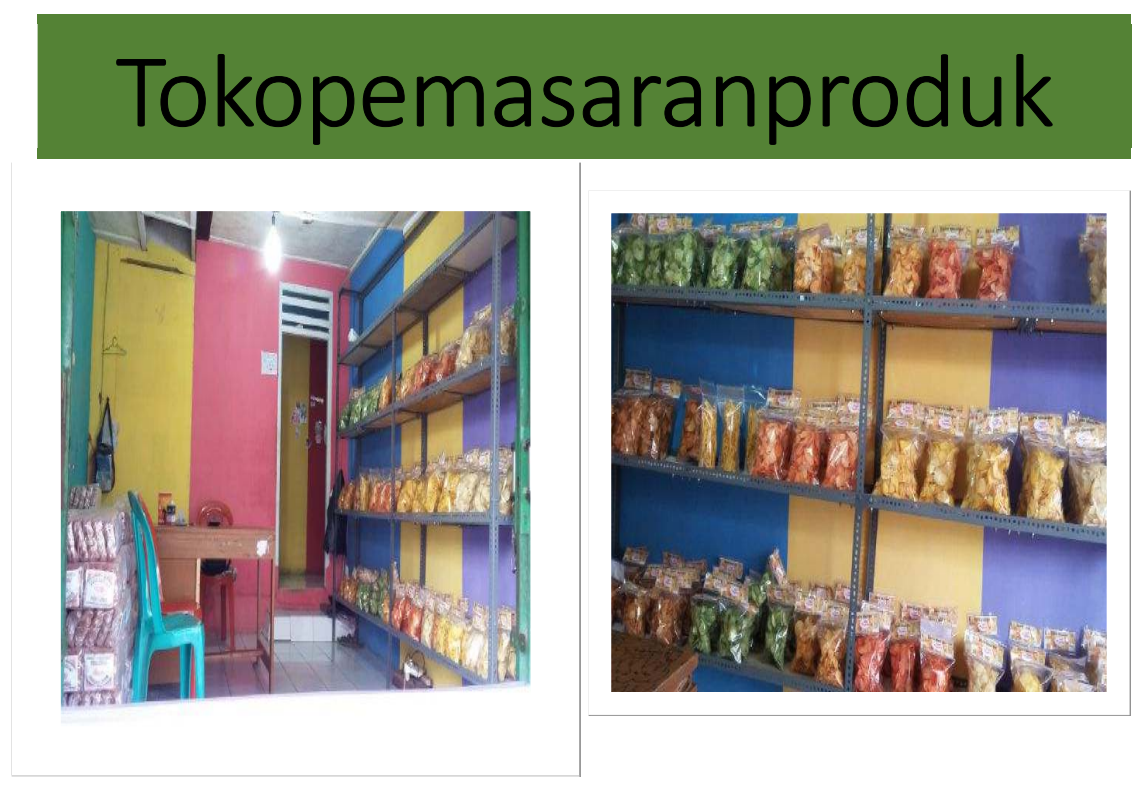

Figure 5. Product Marketing Store

\section{CONCLUSION}

This activity result the following conclusion namely (1) Partners really need assistance to improve their business; (2) Counseling and coaching has increased partner knowledge about the provision of hygienic cassava chips and fix their production lay out; (3) Counseling and training in 
modifying chips packaging has resulted in a variety of diversified cassava chips for different market segments; (4) Counseling and cutting has produced packaging from cassava chips which are more attractive.

\section{REFERENCES}

DISTRICT, J. P. Analisis produksi optimum pada industry keripik singkong (studi kasus pada industry keripik singkong Rajawali di desa Rundeng kecamatan Johan Pahlawan kabupaten Aceh Barat).

Badan Pusat Statistik. (2016). Produksi Ubi Kayu Menurut Provinsi (ton), 1993-2015, http://www.bps.go.id

[BPOM] Badan Pengawas Obat dan Makanan. 2003. Pedoman Cara Produksi Pangan yang Baik untuk Industri RumahTangga (CPPBIRT). Keputusan kepala BPOM 00.05.5.1639.

Boone, L. F., \& Kurtz, D. L. (2000). Pengantar Bisnis, Jilid 2. Erlangga: Jakarta.

Sylvia, R. (2013). Analisis Investasi Pendirian Home Industry Keripik Singkong di Desa Gunung Ulin Kabupaten Kota baru Kalimantan Selatan. Jurnal Ekonomi Manajemen, 7(1).

Usman, H. (2006). Manajemen: teori, praktik, dan riset pendidikan. Jakarta: bumiaksara.

Karipidis, P., Athanassiadis, K., Aggelopoulos, S., \&Giompliakis, E. (2009). Factors affecting the adoption of quality assurance systems in small food enterprises.Food control, 20(2), 93-98.

Kementerian Negara RI. (1996). UndangUndang No 7 Tahun 1996 Tentang Pangan. Jakarta

Lisyanti (2008). EvaluasiPenerapan Cara Produksi Yang Baik (Good Manufacturing Practices) dan Penyusunan SSOP Industri Lidah Buaya di PT. Libe Bumi Abadi. Skripsi. Institut Pertanian Bogor

Muhandri, T., Herawati, D., Budi, F. S., Nuraida, L., Koswara, S., Agista, A. Z., \&Sukmawati, Y. (2017). Kesiapan Usaha Mikro Kecil Menengah Pangan dalam Penerapan ISO 9001: 2008 (Studi Kasus di Palu, Sulawesi Tengah). Agrokreatif Jurnal Ilmiah Pengabdian kepada Masyarakat, 2(2), 61-66.

Rangkuti, K., Mardhiyah, A., \& Putri, A. D. (2015). Added Value Analysis of Singkong Chips on Family Business Group Sipare-Pare Village. AGRIUM: JurnalIlmuPertanian, 19(2).

Stanton, W. J. (1996). Prinsip pemasaran. Jakarta: Erlangga.

Susetyo, J., Simanjuntak, R. A., \& Ramos, J. M. (2010). Perancangan Ulang Tata Letak Fasilitas Produksi dengan Pendekatan Group Technology dan Algoritma Blocplan untuk Meminimasi Ongkos Material Handling. JurnalTeknologi, 3(1), 75-84.

Swastha, D. H. Basu. 1996. Azas-azas Marketing.

Syaputri, R. (2015). Pengaruh Kemasan, Merek dan Harga Terhadap Loyalitas Konsumen Pada UKM Keripik Singkong Sulis di Samarinda, eJournal Ilmu Administrasi Bisnis 3(1): 27-39

Wahyuni, T., \&Nurliza, D. K. PREFERENSI KONSUMEN TERHADAP PEMBELIAN KERUPUK IKAN DI KOTA SINTANG. Jurnal Social Economic of Agriculture, 6(1).

Wignjosoebroto, S., Pabrik, T. L., \& Bahan, P. (2003). Edisi ketiga: Cetakan Ketiga. GunaWidya, Surabaya, 110. 
Wirya, I. (1999). Kemasan yang menjual: menang bersaing melalui kemasan. Gramedia Pustaka Utama.

Yuwono, B., Zakaria, F. R., \& Pandjaitan, N. K. (2012). Faktor-faktor yang mempengaruhi penerapan cara produksi yang baik dan standar prosedur operasi sanitasi pengolahan fillet ikan di Jawa. MANAJEMEN IKM: Jurnal Manajemen Pengembangan Industri Kecil Menengah, 7(1), 10-19. 